УДК 534.22

\title{
Phase Velocities of Ultrasound Waves and Elastic Modules in the IIb Type Synthetic Diamond Single Crystal
}

\author{
Gennady M. Kvashnin * \\ Boris P. Sorokin ${ }^{\dagger}$ \\ Mikhail S. Kuznetsov \\ Sergey A. Terentiev \\ Viktor V. Aksenenkov
}

FSBI «Technological Institute for Superhard and Novel Carbon Materials»,

7a, Tsentral'naya street, Moscow region, Troitsk, 108840

Russia

Sergey I. Burkov

Institute of Engineering Physics and Radio Electronics

Siberian Federal University

Svobodny, 79, Krasnoyarsk, 660041

Russia

Received 01.12.2017, received in revised form 06.02.2018, accepted 25.06.2018

First the results of experimental studies on the propagation of bulk acoustic waves (30-120 MHz) in the IIb type synthetic diamond single crystal have been presented in comparison with the appropriate data in the IIa type synthetic diamond. Data obtained were used to calculate all the elastic moduli of IIb type diamond (in GPa) as $C_{11}=1080.0, C_{12}=149.0$, and $C_{44}=57 \% .4$. Parameter of elastic anisotropy $A$ in the IIb type diamond exceeds by $2.5 \%$ an appropriate value in the IIa type diamond.

PACS: $43.35 . C g$

Keywords: IIb type synthetic diamond, boron doping, elastic moduli, bulk acoustic wave.

DOI: 10.17516/1997-1397-2018-11-5-597-602.

\section{Introduction}

Recently in Federal State Budgetary Institution "Technological Institute for Superhard and Novel Carbon Materials" the IIb type synthetic diamond single crystals have been successfully sintered as sufficiently large specimens with linear dimensions up to $8 \mathrm{~mm}$ in reproducible quality (Fig. 1).

Diamond single crystals have a number of unique properties and characteristics that are of great interest for their potential application in micro- and acoustoelectronics: high mobility of electrons and holes, high temperature stability up to $700 \mathrm{~K}$ of semiconductor devices due to wide gape up to $5.5 \mathrm{eV}$, the highest among the known solids bulk (BAW) and surface (SAW) acoustic waves velocities, high thermal conductivity up to $2200 \mathrm{~W} / \mathrm{m} \cdot \mathrm{K}$, ionizing radiation stability, chemical resistance, etc. Physical properties of diamond are of great importance both in terms

\footnotetext{
*genmih@yandex.ru

†bpsorokin1953@yandex.ru

${ }^{\ddagger}$ sburkov@sfu-kras.ru

(c) Siberian Federal University. All rights reserved
} 


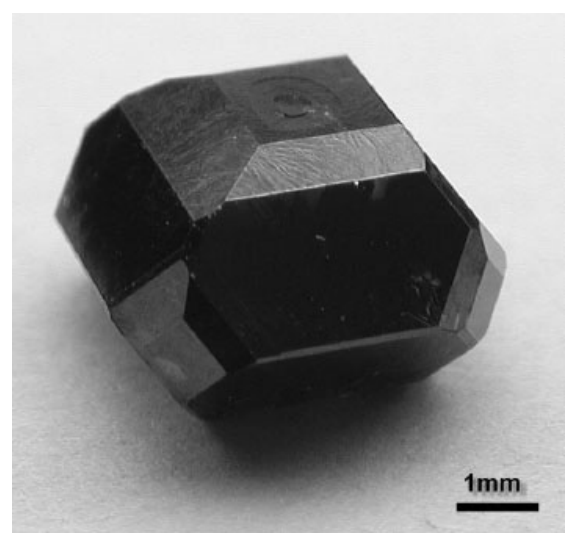

Fig. 1. As-grown IIb type synthetic diamond single crystal

of solid state studies and, in recent years owing to the applied applications of diamond films and single crystals. A full set of accurate data on elastic properties of crystals are necessary in the calculation of anisotropy of ultrasonic wave propagation, estimation of mechanical properties and hardness, etc. Earlier authors [1-3] have developed an accurate method for BAW velocity measuring as a so-called long pulse method based on the high-frequency ultrasound and suitable for samples with small geometric dimensions. In these papers the natural diamond specimens have been investigated. Indirect researching methods, such as X-ray diffuse scattering [4], and Brillouin scattering [5] have also been used to determine the elastic moduli of diamond. Studies of the elastic properties of diamonds produced by the epitaxial growth of CVD-films showed a significant variation of the elastic properties [6]. Recent measurement of elastic moduli in the nitrogen free IIa type synthetic diamond has been executed by the interferometer pulse-phase method [7]. But the elastic properties of the IIb type synthetic diamond doped by boron are unknown now.

Main aims of this study were associated with the measurement of the BAW velocities and calculation of the elastic constants in synthetic semiconductor diamond single crystal of IIb type.

\section{Sample preparation and investigation method}

The IIb type synthetic diamond:B was prepared in FSBI «Technological Institute for Superhard and Novel Carbon Materials» by the High Pressure, High Temperature sintered method with the boron acceptor's content $N_{a} \approx(6-8) \cdot 10^{19} \mathrm{~cm}^{-3}$. Then, after laser cutting the specimen with the 110 and (001) crystalline faces oriented better than 10' was polished to have a nonparallelism of opposite faces up to 1 microns per $\mathrm{cm}$ and a flatness better than $\pm 100 \mathrm{~nm} / \mathrm{mm}$. Linear dimensions of the specimen had the values (in $\mathrm{mm}$ ) along the [110], [110], and [001] crystalline directions as $1.995 \pm 0.003,2.004 \pm 0.001$, and $1.999 \pm 0.001$, respectively. BAW phase velocities were measured by the interferometer pulse-phase method [1,8,9], realized by Ritec Advanced System RAM-5000 in the frequency range 30-120 MHz. Piezoelectric quartz transducers with fundamental frequencies of $11 \mathrm{MHz}$ for longitudinal and $18 \mathrm{MHz}$ for shear waves have been used. The measurements were performed at the harmonics of transducers up to $120 \mathrm{MHz}$. Epoxy resin's acoustic contact between the sample and fused silica buffer has been used. Measuring data were the $f_{n}$ frequencies, satisfying to the condition of the exact phase matching between 
the incident and reflected acoustic waves in the sample. In this case the phase velocity can be calculated by the formula:

$$
V=\frac{2 d f_{n}}{n-\frac{\gamma}{360}},
$$

where $d$ is the sample's dimension along the acoustic wave propagation, $n$ is a number of halfwaves fitting within the sample dimension, and $\gamma$ is the phase shift angle (in degrees) arising for the acoustic wave reflected from the boundary of the "sample-acoustic contact." Whereas there was difficult to determine the layer thickness of an acoustic contact, a special method to minimize its influence has been implemented. For this purpose, the frequency dependence of the BAW velocity due to the phase angle changing has been investigated. As one was shown in $[1,8,10]$, the angle $\gamma$ decreases with the frequency increasing. In this case an integer number $n$ is increased too. In our experiments, the $n$ value was more than 25 for the longitudinal and more than 40 for shear elastic waves. As a result, the $(\gamma / 360)$ correction to the $n$ in the denominator of (1) becomes a negligible small one, and the BAW phase velocity tends asymptotically to the true velocity in an infinite medium [1]. High frequency measurements should also minimize the dispersion errors due to diffraction effects and the acoustic wave's reflections on the lateral side walls of the sample. For example, on the Fig. 2 a typical curve of the frequency dependence for the longitudinal wave velocity $V_{L}$ propagating along the [110] direction of the sample. It is clear that the phase velocity tends to the value of $18326 \mathrm{~m} / \mathrm{s}$ at $120 \mathrm{MHz}$. Note that such frequency dependence is exclusively caused by the presence of an acoustic contact layer.

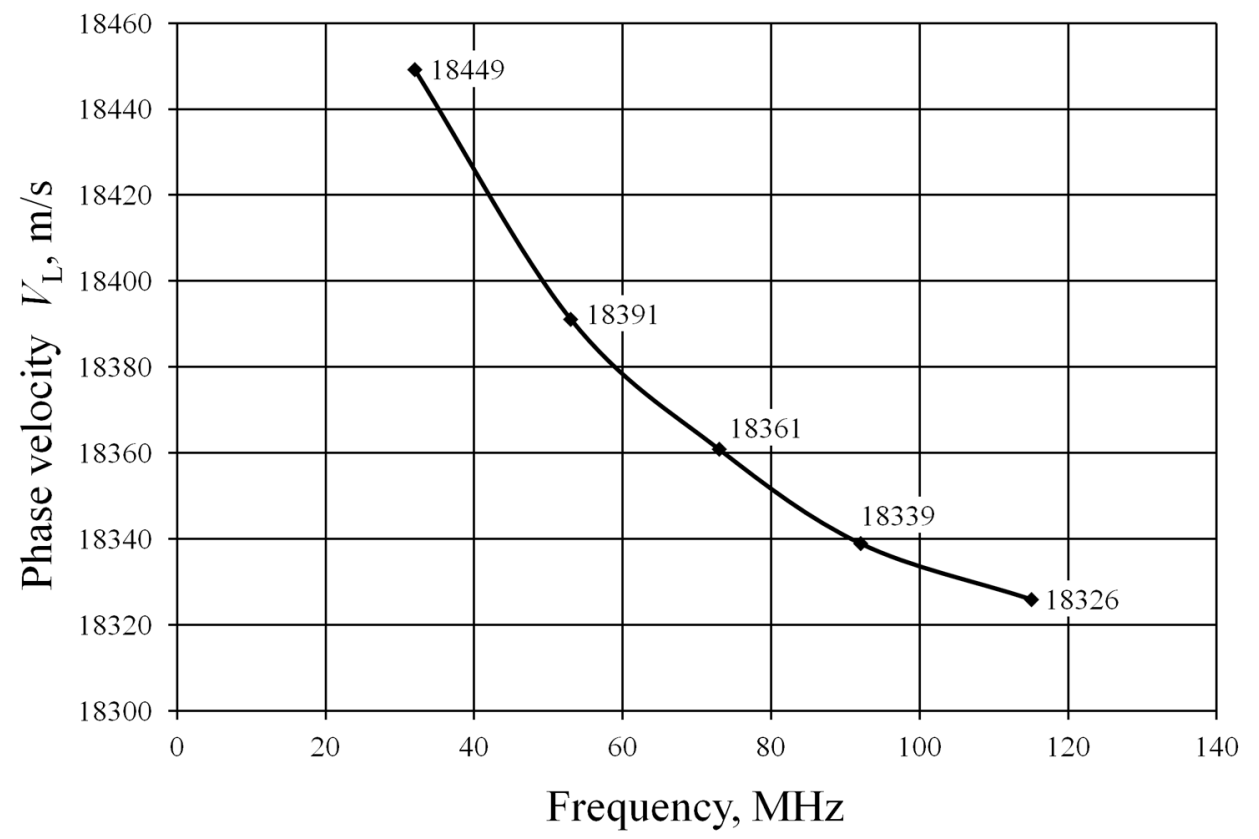

Fig. 2. Frequency dependence of phase velocity of the longitudinal bulk acoustic wave propagating along the $[110]$ crystalline direction in the IIb type diamond

Taking into account the phase error and sample preparation's inaccuracy, the experimental 
error of phase velocity's measuring has been estimated as $0.07 \%$ at $120 \mathrm{MHz}$.

In practice the best experimental results can be obtained if the pure acoustic modes have been investigated only. It is easy to get the relations required for calculation of a complete set of elastic constants $C_{11}, C_{12}$, and $C_{44}$ in cubic crystals in accordance with the above mentioned condition (Tab. 1). As one can see, there are 5 modes which can be available to measure the BAW phase velocities using a sample in the given configuration. Usually the $C_{11}$ and $C_{44}$ constants have been calculated by the first and second equations and then the results obtained could be used to obtain the $C_{12}$ constant from solving the third or fifth equation. In this case, a redundant system of linear equations (Tab. 1) enables to minimize the experimental errors.

Table 1. Relations between the BAW phase velocities and elastic constants $C_{i j}$ in cubic crystals

\begin{tabular}{|c|c|c|}
\hline Mode's number & BAW's type & $\rho V^{2}$ \\
\hline 1 & $L$ & $C_{11}$ \\
\hline 2 & $S$ & $C_{44}$ \\
\hline 3 & $L$ & $\frac{1}{2}\left(C_{11}+C_{12}+2 C_{44}\right)$ \\
\hline 4 & $S_{1}$ & $C_{44}$ \\
\hline 5 & $S_{2}$ & $\frac{1}{2}\left(C_{11}-C_{12}\right)$ \\
\hline
\end{tabular}

$\rho$ is the density of a crystal.

\section{Results and discussion}

Asymptotic values of BAW phase velocities for the investigated sample obtained for a number of crystalline directions and acoustic wave types are shown in the Tab. 2 in comparison with our appropriate data on the synthetic IIa type diamond [7]. As one can see, there is observed the systematical decreasing of the appropriate phase velocities in the IIb type diamond. As far as the crystalline density is involved into all the equations in Tab. 1, it is necessary to know its real value. With this in mind the $\rho$ value was calculated taking into account the unit cell parameter of the IIb type diamond measured by X-ray equipment Panalytical Empyrean. Results on the unit cell parameter and $\rho$ value are shown in the Tab. 3 in comparison with appropriate data on the IIa type diamond [11]. Note that the calculated density of the IIb type diamond is slightly less than that in the IIa type diamond.

Taking into account the relations of the Tab. 1 and the data in the Tabs. 2 and 3, all the elastic moduli of the IIb type diamond as well as elastic anisotropy parameter $A$ have been calculated (Tab. 4).

Table 2. BAW phase velocities of the IIb type diamond single crystal at room temperature

\begin{tabular}{|c|c|c|c|c|c|}
\hline Mode's & Propagation & Polarization (elastic & BAW's & \multicolumn{2}{|c|}{ Phase velocity, m/s } \\
\cline { 5 - 6 } number & direction & dispacement) direction & type & Present paper & IIa type, [7] \\
\hline 1 & {$[100]$} & {$[100]$} & $L$ & $17444 \pm 12$ & 17542 \\
\hline 2 & {$[100]$} & $\perp(100)$ & $S$ & $12826 \pm 9$ & 12828 \\
\hline 3 & {$[110]$} & {$[110]$} & $L$ & $18326 \pm 13$ & 18333 \\
\hline 4 & {$[110]$} & {$[001]$} & $S_{1}$ & $12816 \pm 9$ & 12829 \\
\hline 5 & {$[110]$} & {$[110]$} & $S_{2}$ & $11514 \pm 8$ & 11659 \\
\hline
\end{tabular}


Table 3. Unit cell parameter and calculated density in the IIb type diamond at room temperature

\begin{tabular}{|c|c|c|c|}
\hline \multicolumn{2}{|c|}{ Unit cell parameter $a, \AA$} & \multicolumn{2}{c|}{ Calculated density $\rho, \mathrm{kg} / \mathrm{m}^{3}$} \\
\hline IIa type diamond [11] & $\begin{array}{c}\text { Our data IIb } \\
\text { type diamond }\end{array}$ & IIa type diamond [11] & $\begin{array}{c}\text { Our data IIb } \\
\text { type diamond }\end{array}$ \\
\hline 3.56691 & $3.5676 \pm 0.0002$ & 3516 & $3510 \pm 1$ \\
\hline
\end{tabular}

Table 4. Elastic moduli $C_{i j}(\mathrm{GPa})$ of the IIb type diamond at room temperature in comparison with previous data

\begin{tabular}{|c|c|c|}
\hline & This work & {$[7]$} \\
\hline$C_{11}$ & $1080.0 \pm 1.5$ & $1081.9 \pm 1.0$ \\
\hline$C_{12}$ & $149.0 \pm 0.8$ & $125.2 \pm 0.8$ \\
\hline$C_{44}$ & $577.4 \pm 0.8$ & $578.6 \pm 0.2$ \\
\hline$A=\frac{2 C_{44}}{C_{11}-C_{12}}$ & 1.24 & 1.21 \\
\hline
\end{tabular}

Comparison of data obtained shows that the main elastic moduli $C_{11}$ and $C_{44}$ of the IIb type diamond are close to appropriate constants in the IIa type diamond within an experimental error. One can suppose that the hardness of the IIb type diamond should be the similar as that in the IIa type diamond. The discrepancy in the $C_{12}$ values can be explained in terms of a slight distortion of the diamond's cubic lattice as a result of boron doping. Indeed, the parameter of elastic anisotropy $A$ in the IIb type diamond (see Tab. 4) exceeds by $2.5 \%$ an appropriate value in the IIa type diamond. Such discrepancy can't be explained by the error in the measurement of elastic constants.

This work was supported by the Ministry of Education and Science of the Russian Federation (project ID RFMEFI59317X0007; the agreement no. 14.593.21.0007); the work was done using the Shared-Use Equipment Center "Research of Nanostructured, Carbon and Superhard Materials" FSBI TISNCM.

\section{References}

[1] H.J.McSkimin, W.L.Bond, Elastic Moduli of Diamond, Phys. Rev., 105(1957), no. 1, $116-121$.

[2] H.J.McSkimin, P.Andreatch, P.Glynn, The Elastic Stiffness Moduli of Diamond, J. Appl. Phys., 43(1972), no. 3, 985-987.

[3] H.J.McSkimin, P.Andreatch, The Elastic Stiffness Moduli of Diamond as a Function of Pressure and Temperature, J. Appl. Phys., 43(1972), no. 7, 2944-2948.

[4] E.Prince, W.A.Wooster, Determination of Elastic Constants of Crystals from Diffuse Reflexions of X-rays. III. Diamond, Acta Cryst., 6(1953), no. 6, 450-454.

[5] E.S.Zouboulis, M.Grimsditch, S.A.K.Ramdas, Rodriguez, Temperature dependence of the elastic moduli of diamond: A Brillouin-scattering study, Phys. Rev. B., 57(1998), no. 5, 2889-2896. 
[6] P.Djemia, A.Tallaire, J.Achard, F.Silva, A.Gicquel, Elastic properties of single crystal diamond made by CVD, Diam. and Rel. Mat., 16(2007), no. 4-7, 962-965.

[7] B.P.Sorokin, G.M.Kvashnin, M.S.Kuznetsov, A.V.Telichko, S.I.Burkov, Influence of the Temperature and Uniaxial Pressure on the Elastic Properties of Synthetic Diamond Single Crystal, Proc. IEEE Ultrasonics Symp., Dresden, Germany, 2012, 763-766.

[8] H.J.McSkimin, Ultrasonic Measurement Techniques Applicable to Small Solid Specimens, J. Acoust. Soc. Am., 22(1950), no. 4, 413-418.

[9] H.J.McSkimin, Use of High Frequency Ultrasound for Determining the Elastic Moduli of Small Specimens, Proc. Nat. Electron. Conf., Chicago, USA, 1956, 25-43.

[10] H.J.McSkimin, Notes and References for the Measurement of Elastic Moduli by Means of Ultrasonic Waves, J. Acoust. Soc. Am., 33(1961), no. 5, 606-615.

[11] K.Haruna, H.Maeta, K.Ohashi, T.Koike, Thermal Expansion Coefficient of Synthetic Diamond Single Crystal at Low Temperatures, Jpn. J. Appl. Phys. (Pt. 1)., 31(1992), 2527.

\section{Фазовые скорости ультразвуковых волн и упругие модули синтетического монокристалла алмаза IIb типа}

\section{Геннадий М. Квашнин Борис П. Сорокин Михаил С. Кузнецов Сергей А. Терентьев \\ Виктор В. Аксёненков} Технологический институт сверхтвердых и новых углеродных материалов Центральная, 7а, Москва, Троицк, 142190 Россия

Сергей И. Бурков Институт инженерной физики и радиоэлектроники Сибирский федеральный университет Свободный, 79, Красноярск, 660041

Россия

$\overline{П р е д с т а в л е н ы ~ п е р в ы е ~ р е з у л ь т а т ы ~ э к с п е р и м е н т а л ь н ы х ~ и с с л е д о в а н и и ̆ ~ р а с п р о с т р а н е н и я ~ о б ъ е м н ы х ~}$ акустических волн (30-120 МГц) в синтетическом монокристалле алмаза ІІь типа в сравнении с соответствующими данными в синтетическом алмазе ІІа типа. Полученные данные были использовань для расчета всех модулей упругости $C_{i j}$ (в ГПа) алмаза IIb типа: $C_{11}=1080.0$, $C_{12}=149.0$ и $C_{44}=577.4$. Параметр упругой анизотропии в алмазе IIb типа превышает на 2,5\% соответствующее значение в алмазе II типа.

Ключевые слова: синтетический алмаз IIb типа, легирование бором, объемная акустическая волна, модули упругости. 